\title{
ANALISIS WACANA KOHESI DAN KOHERENSI PADA TEKS CERPEN, TEKS PROSEDUR, TEKS LINGKUNGAN DAN KEMUNGKINAN PEMBELAJARAN DI SEKOLAH
}

diajukan untuk memenuhi salah satu persyaratan mata kuliah Wacana Bahasa Indonesiayang diampu oleh Prof. Dr. Syahrul R., M.Pd.

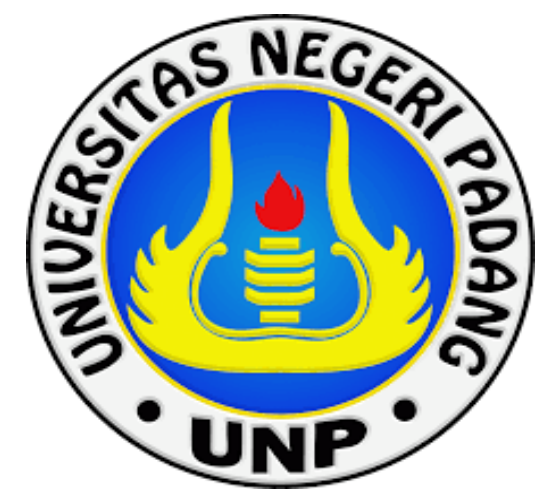

10. NINING SUNDARI

NIM 17016034

\author{
PROGRAM STUDI PENDIDIKAN BAHASA DAN SASTRA INDONESIA \\ JURUSAN BAHASA DAN SASTRA INDONESIA DAN DAERAH \\ FAKULTAS BAHASA SASTRA DAN SENI \\ UNIVERSITAS NEGERI PADANG




\section{KATA PENGANTAR}

Puji syukur atas kehadirat Allah SWT yang telah melimpahkan rahmat dan karunia-Nya sehingga penulis dapat menyelesaikan makalah yang berjudul "Analisis Wacana Kohesi dan Koherensi pada teks cerpen, Teks Prosedur, Teks Lingkungan dan Kemungkinan Pembelajaran di Sekolah". Sebagai bagian dari tugas akhir mata kuliah "Wacana Bahasa Indonesia". Tidak lupa penulis ucapkan terima kasih kepada bapak dosen Prof Dr. Syahrul R., M.Pd. selaku dosen mata kuliah "Wacana Bahasa Indonesia" yang telah membantu dan membimbing penulis dalam pengerjaan makalah ini. Penulis juga mengucapkan terima kasih kepada teman-teman yang telah memberi kontribusi, baik secara langsung maupun tidak langsung dalam pembuatan makalah ini.

Tentunya ada hal-hal yang ingin penulis berikan kepada masyarakat terutama pelajaran dari hasil makalah ini. Oleh karena itu, penulis berharap semoga makalah ini menjadi sesuatu yang berguna bagi kita semua. Penulis menyadari bahwa dalam menyusun makalah ini masih jauh dari kesempurnaan, untuk itu penulis sangat mengharapkan kritik dan saran yang bersifat membangun guna sempurnanya makalah ini. Penulis berharap semoga makalah ini bisa bermanfaat bagi penulis khususnya dan bagi pembaca pada umumnya.

Padang, Mei 2020

Nining Sundari 


\section{DAFTAR ISI}

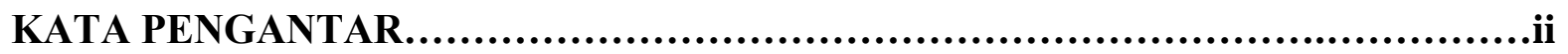

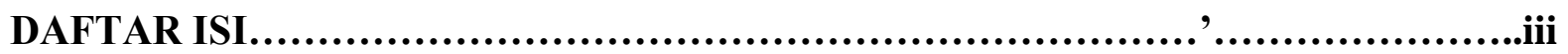

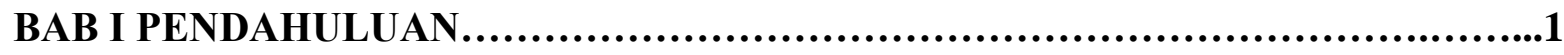

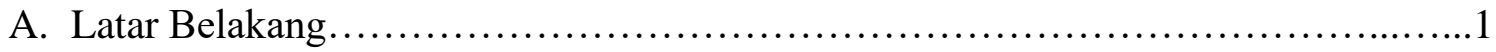

B. Rumusan Masalah.................................................................

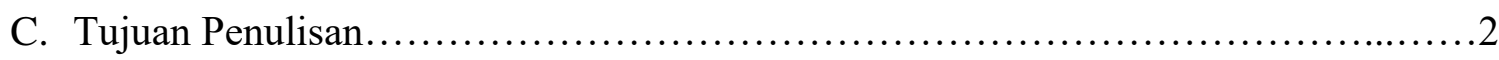

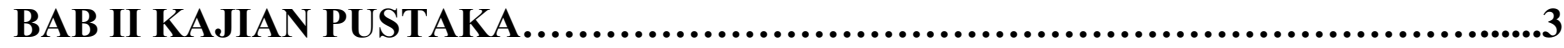

BAB III HASIL DAN PEMBAHASAN .............................................6

A. Analisis Teks Cerpen “Kembang Api Pembawa Petaka” karya Pradipta Alamsah Reksaputra berdasarkan Kohesi dan Koherensi..................................6

B. Analisis Teks Prosedur "Cara Membuat Wrdang Jahe yang Enak dan Sederhana" berdasarkan Kohesi dan Koherensi ........................................... 8

C. Analisis Teks Wacana Lingkungan " Kerusakan Lingkungan Hidup dan Penyebabnya" berdasarkan Kohesi dan Koherensi..................................11

D. Deskripsi Kemungkinan Pembelajaran Ketiga Wacana tersebut di Sekolah...........12

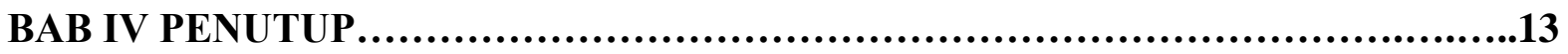

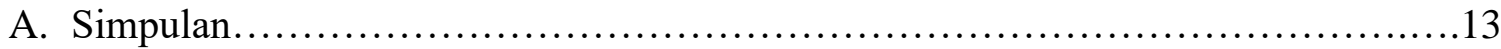

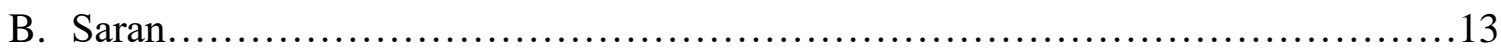

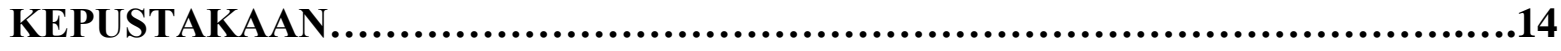




\section{BAB I \\ PENDAHULUAN}

\section{A. Latar Belakang}

Menurut Poerwadarminta (dalam Baryadi, 2002:1) kata wacana berasal dari kata vacana 'bacaan' dalam bahasa Sanskerta. Kata vacana itu kemudian masuk ke dalam bahasa Jawa Kuno dan bahasa Jawa Baru wacana atau 'bicara, kata, ucapan'. Kata wacana dalam bahasa Jawa Baru itu kemudia diserap ke dalam bahasa Indonesia menjadi wacana 'ucapan, percakapan, kuliah'. Kata wacana dalam bahasa Indonesia dipakai sebagai padanan kata discourse dalam bahasa Inggris. Secara etimologi kata discourse itu berasal dari bahasa latin discursus 'lari kian kemari'. Menurut Baryadi(2002:17), hubungan antar bagian wacana ada dua jenis, yaitu (1) hubungan bentuk yang disebut dengan kohesi (Cohesion) dan (coherence).

Siregar (2019) mengatakan bahwa wacana adalah unit bahasa yang terlengkap di atas kalimat yang memiliki konsep, gagasan, pikiran, atau ide yang dapat dipahami oleh pembaca dan pendengar. Sedangkan menurut Kridalaksana (dalam Insani, 2018) wacana merupakan satuan bahasa terlengkap dan satuan gramatikal tertinggi dalam hierarki gramatikal. Sebagai tataran tertinggi dalam hierarki kebahasaan, wacana tidak merupakan susunan kalimat secara acak, tetapi merupakan satuan bahasa, baik lisan maupun tulis. Berbeda dengan pendapat Widyaningrum (2017) wacana merupakan tingkatan yang paling tinggi di dalam hierarki pembicaraan sintaksis setelah frase, klausa dan kalimat. Wacana juga suatu tulisan yang dapat berupa kata, kalimat, paragraf, bab atau beberapa bab. Menurut Hanafiah (2014) wacana adalah komunikasi verbal, percakapan, keseluruhan tutur yang merupakan suatu kesatuan. Menurut Alwi, et al (dalam Nurfitriani, et al, 2018) wacana adalah sebuah rentetan kalimat yang menghubungkan prosisi lain dan membentuk satu kesatuan. Di samping itu, wacana merupakan kesatuan bahasa terlengkap dan terbesar dari kalimat atau klausa dengan kohesi dan koherensi yang tinggi dan berkesinambungan, yang mampu mempunyai awal dan akhir yang nyata, serta dapat disampaikan secara lisan dan tertulis.

Berdasarkan pendapat para ahli tersebut, dapat disimpulkan bahwa wacana adalah ucapan, percakapan, kata, atau kalimat yang menghubungkan posisi lain dan membentuk satu kesatuan bahasa terlengkap dan terbesar dari kalimat atau klausa dengan kohesi dan koherensi yang tinggi dan berkesinambungan. 


\section{B. Rumusan Masalah}

1. Bagaimana analisis wacana kohesi dan koherensi dalam teks cerpen?

2. Bagaimana analisis wacana kohesi dan koherensi dalam teks prosedur?

3. Bagaimana analisis wacana kohesi dan koherensi dalam teks lingkungan?

4. Bagaimana kemungkinan pembelajaran ketiga wacana tersebut di sekolah?

\section{Tujuan Penulisan}

1. Untuk mendeskripsikan analisis wacana kohesi dan koherensi dalam teks cerpen.

2. Untuk mendeskripsikan analisis wacana kohesi dan koherensi dalam teks prosedur.

3. Untuk mendeskripsikan analisis wacana kohesi dan koherensi dalam teks lingkungan.

4. Untuk mendeskripsikan kemungkinan pembelajaran ketiga wacana tersebut di sekolah. 


\section{BAB II}

\section{KAJIAN PUSTAKA}

Wacana memiliki unsur pendukung yang sangat lengkap dan kompleks. Unsur tersebut terdiri atas unsur verbal (linguistik) dan unsur nonverbal (nonlinguistik). Analisis wacana memiliki peran penting terhadap pembelajaran bahasa Indonesia di Sekolah, terutama pada keterampilan berbahsa (Andayani, 2015). Pembelajaran bahasa Indonesia menjadi dasar untuk menyampaikan mata pelajaran lainnya ketika berada didalam kelas. (Syofiani, et. Al,2018). Salah satu keterampilan yang paling penting yaitu keterampilan menulis. (Arviyana, et.al, 2017). Keterampilan menulis ialah keterampilan paling penting dipelajari segala bahasa ( Yantama, et.al, 2013). Sehingga setiap orang perlu memiliki keterampilan dalam menulis.

Selain itu aspek kohesi dan koherensi juga berkenaan dengan wacana. Baryadi (2002:1718) mengatakan bahwa kohesi berkenaan dengan hubungan bentuk antara bagian-bagian dalam suatu wacana. Berdasarkan perwujudan lingualnya, membedakan dua jenis kohesi, yaitu kohesi gramatikal dan kohesi leksikal. Kohesi gramatikal adalah keterikatan gramatikal antara bagianbagian wacana, sedangkan Kohesi leksikal adalah keterikatan leksikal antara bagian-bagian wacana.

Menurut Baryadi (2002:29) koherensi adalah keterkaitan semantis antara bagian-bagian wacana. Koherensi wacana dapat dibedakan menjadi koherensi (1)wacana eksposisi, (2) wacana deskripsi, (3) wacana narasi. Koherensi ini sering ditunjukkan oleh konjungsi yang menyatakan hubungan temporal (lalu, kemudian, sesudah itu), penanda kala (dulu, sekarang), dan penanda aspek (akan, belum, sudah). (4) wacana prosedural, didomin asi oleh koherensi pentahapan, yaitu tahap-tahap terjadinya peristiwa, dan (5) wacana dialog, didominasi oleh koherensi stimulusrespon, misalnya fatis, informatif, pengukuhan, penolakan, dan negosiatif.

Sukma, et al (2019 : 104 ) mengatakan bahwa Literasi sangat penting bagi siswa karena keterampilan literasi akan berpengaruh terhadap keberhasilan belajar mereka dan kehidupannya. Keterampilan literasi yang baik akan membantu siswa dalam memahami teks lisan, tulisan, maupun gambar/visual. Selanjutnya Mulyadi (dalam Sukma, et al, 2019) menyatakan kesadaran literasi itu penting untuk ditumbuhkembangkan, karena bisa membuat para siswa menjadi cerdas dalam melihat masalah dalam kehidupannya. Saat ini, kata literacy sangat populer di kalangan komunitas akademik. Rendahnya tingkat pengetahuan dan pemahaman informasi di Indonesia, 
sering dikaitkan dengan rendahnya tingkat literasi masyarakat. Beberapa lembaga survei menyatakan fakta tentang rendahnya budaya literasi di Indonesia. Programme for International Student Assessment (PISA) menyebutkan pada tahun 2012 budaya literasi di Indonesia menempati urutan ke-64 dari 65 negera yang disurvei.

Menurut Sukma, et al (2018) literasi dapat dipahami sebagai keterampilan memahami huruf, dan juga kemampuan membaca dan menulis. Sedangkan menurut Sukma, et al (2019) literasi sangat penting bagi siswa karena keterampilan literasi akan berpengaruh terhadap keberhasilan belajar mereka dan kehidupannya. Keterampilan membaca yang baik akan membantu siswa memahami teks lisan, tulisan, maupun teks visual. Menurut Sukma, et al (2017) sebagai dasar keterampilan membaca harus intens dan tegas, oleh karena itu kegiatan membaca pendahuluan harus dilayani dan diimplementasikan dengan sunggu-sungguh.

Literasi dapat diartikan sebagai keterbukaan wawasan, yaitu kemampuan individu dalam mengolah informasi dan pengetahuan untuk keterampilan hidup. Secara garis besar, literasi berkaitan erat dengan istilah wacana mahir, yaitu kemampuan seluruh bahasa mencakup kemampuan untuk mendengarkan, berbicara, membaca, dan menulis, serta kemampuan untuk berpikir elemen-elemen yang ada di dalamnya.

Pembelajaran di sekolah sangat penting bagi siswa dalam menulis berbagai teks. Oleh sebab itu, keterampilan menulis harus dimiliki siswa mulai dari tingkat Sekolah Dasar. Setelah siswa mampu dalam menulis maka siswa dapat mempelajari berbagai teks, seperti teks cerpen, teks prosedur, teks lingkungan, dan teks lainnya. Menurut Putri, et al (2013) dalam pembelajaran lesson study merupakan model profesi guru dengan menerapkan tiga prinsip pembelajaran yang harus dilakukan oleh guru yaitu, perencanaan, pelaksanaan, dan refleksi. Percakapan dalam pembelajaran di kelas merupakan realitas komunikasi menggunakan bahasa yang berlangsung dalam interaksi sosial, karena pada prinsipnya, percakapan tersebut menggunakan bahasa sebagai alat komunikasi dalam interaksi sosial. Menurut Ramadhan, et al (2019) guru harus mengadaptasi metode pengajaran mereka sehingga mereka dapat memotivasi siswa untuk terlibat dalam pembelajaran partisipatif aktif.

Keterampilan menulis teks cerpen siswa masih rendah karena siswa merasa kesulitan dalam menuangkan gagasan atau ide dalam menulis, pemahaman siswa terhadap isi cerita juga 
sangat rendah karena bahan bacaan yang dimiliki siswa belum baik. Kesulitan dalam menulis siswa. Dilihat dari siswa yang kurang memahami inti dari teks cerita, secara psikologis siswa cendrung tidak memahami secara mendalam. Dalam menulis teks cerpen, siswa banyak yang tidak memperhatikan penggunaan bahasa yang efektif. Guru yang berperan dalam proses pembelajaran harus memperhatikan bagaimana menemukan teks cerpen yang menarik bagi semua siswa. Teks prosedur juga penting dipelajari siswa. Menurut Pradana (dalam Arviyana, et al, 2017) pembelajaran menulis teks prosedur menjadi penting karena setiap siswa mampu memahami dan mengutarakan idenya.

Menurut Ramadhan, et al (2019) pendidikan lingkungan adalah upaya bersama yang secara sudah diatur untuk mengajarkan atau menarik perhatian manusia tentang bagaimana fungsi lingkungan alam dan bagaimana manusia dapat mengelola dan melindunginya. Jadi, bukan hanya teks cerpen dan teks prosedur saja yang penting dalam pembelajaran di sekolah, tetapi teks lingkungan juga sangat penting agar siswa dapat mengetahui dan menjaga lingkungan dengan baik. 


\section{BAB III \\ PEMBAHASAN}

\section{A. Analisis Wacana Kohesi dan Koherensi dalam Teks Cerpen "Kembang Api Pembawa Petaka" Karya Pradipta Alamsah Reksaputra}

Hubungan kohesi dalam cerpen “ kembang api pembawa petaka” karya Pradipta Alamsah Reksaputra

\section{Kohesi Leksikal}

Dalam cerepen "kembang api pembawa petaka" ditemukan data-data yang mengandung kohesi leksikal, yang ditunjukan dengan penggunaan kata, frasa, klausa dan kalimat yang mengandung piranti kohesi gramatikal berupa (pengulangan kata), sisnonim (persamaan kata), hiponim (Relasi kata), meronim (Bagian kata) dan antonym ( perlawanan kata).

a. Repetisi pengulangan kata

“Aku lebih sering menghabiskan waktuku di hutan".

"Ini baru pertama kalinya aku pergi ke desa".

"Tiba-tiba aku berubah wujud diluar kendaliku"

"Memang aku sadar, aku sedikit berbeda dengan kebanyakan manusia" "Karena aku adalah manusia serigala"

Repetsisi dalam data-data tersebut terjadi berulang-ulang karena kata" Aku" yang merupakan tokoh utama dalam cerita ini. Kata aku pada beberapa data tersebut untuk menekankan pembaca betapa penting tokoh aku dalam cerpen tersebut.

b. Sinonim ( persamaan kata)

Sinonim merupakan persamaan kata. Berikut contoh sinonim dalam cerpen "kembang api membawa petaka" .

"Tapi sesungguhnya, ayahku sedikit takut, merasa aku masih belum siap untuk berbaur" . dalam kata di atas terdapat persamaan makna, yaitu "sedikit takut" dan kata " belum siap" kata-kata tersebut hamper memiliki maksud yang sama, yaitu belum sepenuhnya yakin untuk pergi kedesa, merasa masih ragu.

c. Hiponim(relasi kata) 
“ dilapangan, di desa dan ketika kembang api..". Dalam kata di lapangan dan di desa. Kedua kata ini kedu kata ini memiliki pengertian bawahan dari "perkampungan". Kata "lapangan" dan " desa" terdapat dalam sebuah "perkampungan".

d. Antonim( perlawanan kata)

Dalam cerpen ini terdapat antonim atau perlawanan kata. Berikut contohnya "aku manusia srigala sedangkan mereka manusia biasa" dalam cerpen ini " manusia srigala" dan "manusia biasa" saling berkawanan, atau tidak sama.

\section{Koherensi}

koherensi adalah keterkaitan semantis anatara bagian-bagian wacana. Bagian-bagian wacana narasi didominasi oleh kohorensi "kronologis" atau " hubungan rangkaian waktu". Kohorensi ini sering ditunjuk oleh konjungsi yang menyetakan hubungan temporal ( lalu, kemudian, sesudah itu), penanda kala( dulu, sekarang), penanda aspek(akan, dulu, sudah). Berikut contoh koherensi dalam cerpen " kembang api pembawa petaka" karya Pradipta Alamsah Reksaputra.

\section{a. Cause (Hubungan sebab)}

"aku memang manusia srigala tetapi aku tidak buas. Aku melihat ke arah lain ke arah orang-orang yang seperti kerbau. Mereka tidak dilempari batu, padahal mereka terlihat lebih dekil dan berwarna gelap dariku. Kenapa hanya aku yang dilempari batu?"

Pada contoh tersebut tampak sebab ia dilempari batu karena ia berubah wujud menjadi srigala, namun ia tidak terima, masih ada wujud manusia kerbau yang lebih jelek, namun tidak dilempari batu.

b. Reason(Hubungan alasan)

“Ke-kenapa, Ayah?” tanyaku yang masih syok akibat semua orang yang tampak membenciku". " mereka tidak tahu kehidupan kita, dan bagaimana kita. Kita tidak lah buas" Dari contoh di tersebut tampak hubungan berserta alasannya.

\section{c. Consequence (Hubungan Konsekuensi)}

"serigala itu cukup keren. Jika berubah wujud menjadi serigala, aku bisa berlari sangat cepat, aku bisa mengejar seekor rusa, dan menerkamnya dengan mudah. Indraku juga jadi 
semakin tajam. Aku bisa mencium dan mendengar sesuatu dari jarak jauh. Kemampuan ini sangat berguna untuk berburu mangsa. Terakhir adalah warna bulu tubuhku yang lucu, berwarna cokelat dengan warna putih di bagian perut, ujung kaki, ujung telinga, dan ujung ekorku".

Dari contoh tersebut, Nampak jika serigala tentu akan berubah wujud menjadi memiliki bulu. Karena tokoh dalam cerita ini merupakan manusia serigala. Jadi ia harus menerima konsekuensi menjdi manusia serigala, dan dapat berubah wujud.

\section{B. Analisis Wacana Kohesi dan Koherensi dalam Teks Prosedur}

\section{Analisis Wacana Kohesi}

Berikut ini analisis kohesi gramatikal dalam teks prosedur "Cara Membuat wedang jahe yang enak dan sederhana " yaitu:

\section{a. Penunjukan}

Kohesi penunjukan dapat dibedakan menjadi dua jenis, yaitu penunjukan anaforis dan penunjukan kataforis. Contoh kohesi penunjukkan yang terdapat dalam cerpen ini yaitu dengan menggunakan kata Ini dan Itu.

"2. Dapat menurunkan berat badan

Bagi Parents yang berniat untuk menurunkan berat badan secara alami dan sehat, maka bisa dibantu dengan minum jahe. Walaupun pendapat ini masih dibutuhkan penelitian lebih lanjut, tapi minum wedang jahe memang bisa membuat Parents merasa kenyang.

4. Meredakan nyeri sendi dan otot

Minum jahe juga telah lama dipercaya mampu meredakan nyeri sendi dan otot akibat peradangan. Tak hanya itu, minuman jahe juga dapat digunakan sebagai obat alami asam surat, berkat sifat antiradang yang dimiliki jahe.

5. Mencegah risiko penyakit jantung

Kandungan antioksidan, mineral, dan asam amino dalam minuman jahe dipercaya dapat membantu mencegah risiko penyakit jantung. Selain itu, minuman jahe juga dapat meningkatkan sirkulasi darah, menurunkan kolesterol, meredakan nyeri ulu hati, mencegah serangan jantung, dan menurunkan tekanan darah.” 
Contoh kalimat penunjukan kataforis dalam cerpen ini yaitu dengan menggunakan kata Berikut ini dan yaitu.

"Selain resep tersebut, ada juga pilihan resep wedang jahe lainnya, yaitu wedang jahe rempah. Berikut ini adalah bahan dan cara membuatnya.

Selain resep tersebut, ada juga pilihan resep wedang jahe lainnya, yaitu wedang jahe rempah."

\section{b. Penggantian}

Contoh kalimat kohesi penggantian dalam Teks ini adalah "Memasuki musim hujan, kita seringkali merasakan kedinginan dan ingin minum sesuatu yang menghangatkan badan. Wedang jahe adalah salah satu minuman tradisional yang sering digunakan untuk menghangatkan badan saat cuaca dingin, juga bagi mereka yang sedang terkena flu."

Dari contoh-contoh di atas terlihat bahwa kata-kata yang dipakai untuk kohesi penggantian persona juga bersifat deiktis. Oleh sebab itu, kata-kata tersebut disebut juga deiksis persona.

\section{c. Pelesapan atau Penghilangan}

Contoh kalimat pelesapan atau penghilangan dalam teks ini tidak di temukan.

\section{d. Perangkaian}

Contoh kalimat perangkaian dalam teks ini adalah "2. Setelah mendidih, kecilkan api, tapi jangan sampai mati. Setelah itu, masukkan gula aren, gula batu dan madu."

Berikut analisis wacana kohesi leksikal dalam teks prosedur "Cara membuat wedang jahe yang enak dan sederhana" yaitu.

\section{1) Kohesi Pengulangan}

Contoh kalimat kohesi pengulangan dalam teks prosedur ini tidak ditemukan.

\section{2) Kohesi Hiponimi}

Contoh kalimat kohesi hiponimi dalam teks prosedur ini tidak ditemukan. 


\section{3) Kohesi Sinonimi}

Contoh kalimat kohesi sinonimi dalam teks prosedur ini tidak ditemukan.

\section{4) Kohesi Antonimi}

Contoh kalimat kohesi antonimi dalam teks ini tidak ditemukan.

\section{5) Kohesi Kolokasi}

Contoh kalimat kohesi kolokasi dalam teks prosedur ini tidak ditemukan.

\section{Analisis Wacana Koherensi}

Koherensi dalam wacana ada wacana eksposisi, wacana deskripsi,wacana narasi, wacana prosedural dan wacana dialog.

\section{a. Koherensi Wacana Eksposisi}

Setelah mendidih, kecilkan api, tapi jangan sampai mati. Setelah itu, masukkan gula aren, gula batu dan madu.

Pada kalimat tersebut terlihat bahwa alineanya memiliki koherensi temporal.

\section{b. Koherensi Wacana Deskripsi}

Jenis koherensi dalam wacana deskripsi memiliki koherensi perincian, rincian, dan posesif. Salah satu contoh koherensi wacana deskripsi adalah

"2. Dapat menurunkan berat badan

Bagi Parents yang berniat untuk menurunkan berat badan secara alami dan sehat, maka bisa dibantu dengan minum jahe. Walaupun pendapat ini masih dibutuhkan penelitian ....”

\section{c. Koherensi Wacana Narasi}

“2. Bersihkan jahe dan iris setebal $2 \mathrm{~cm}$. Lalu, iris gula merah dan tidak lupa untuk mencuci sereh.” Pada kalimat tersebut terlihat menyatakan berbagai peristiwa yang terjadi secara kronologis.

\section{d. Koherensi Wacana Prosedural}

1. Siapkan semua bahan wedang jahe.

2. Bersihkan jahe dan iris setebal $2 \mathrm{~cm}$. Lalu, iris gula merah dan tidak lupa untuk mencuci sereh.

3. Siapkan panci untuk merebus air dan semua bahan. 
4. Masukkan semua bahan secara bersamaan untuk direbus.

5. Masak wedang jahe hingga mendidih dan harum. Jangan lupa juga untuk test rasanya sesekali.

6. Sambil menunggu wedang jahe mendidih, siapkan gelas saji.

7. Setelah mendidih, saring air wedang jahe sebelum disantap.

8. Wedang jahe dapat disajikan secara polos atau bisa juga ditambahkan dengan isian sekoteng atau kental manis, tergantung selera masing-masing.

Pada kalimat tersebut menyatakan perbuatan yang dilakukan secara bertahap atau berurutan.

\section{e. Koherensi Wacana Dialog}

Contoh kalimat koherensi wacana dialog dalam teks prosedur ini tidak ditemukan.

\section{Analisis Kohesi dan Kohorensi dalam Teks "Kerusakan Lingkungan Hidup dan Penyebabnya"}

1. Kohesi Gramatikal Penunjukan Anaforis

(1) Penunjukan anaforis yaitu, " Kerusakan lingkungan hidup di Indonesia sudah semakin parah. Hal tersebut membuat lingkungan tempat tinggal menjadi tidak nyaman dan kian parah.

2. Kohesi penggantian

(2) Dapat dilihat dari contoh "mereka seharusnya sadar betapa pentingnya menjaga lingkungan hidup. Ketika lingkungan hidup sudah rusak akan banyak permasalahan yang muncul".

3. Koherensi Kronologis

(3) Zaman sekarang manusia kurang menyadari betapa pentingnya menjaga lingkungn. Jika lingkungan sudah rusak, maka akan terjadi berbagai bencana alam yang menyebabkan manusia semakin kesusahan.

4. Koherensi Kontras

(4) Manusia membuang sampah sembarangan tanpa berfikir dampak yang akan terjadi. Air menjadi tercemar dan tumpukan sampah mengakibatkan terjadinya banjir dilingkungan tersebut. Namun hal tersebut masih di anggap remeh oleh masyarakat. Banyak masyarakat yang belum sadar akan pentingnya menjaga lingkungan hidup. 


\section{Deskripsi Kemungkinan Pembelajaran Ketiga Wacana Tersebut di Sekolah}

Pembelajaran siswa berbasis teks ialah proses belajar berbahasa Indonesia yang dilakukan oleh siswa yang berawal dari pemahaman teks hingga mampu membuat teks. Pembelajaran berbasis teks merupakan ciri khas dari pembelajaran bahasa Indonesia yang ada pada kurikulum 2013 (Isodarus, 2017). Dalam pembelajaran bahasa Indonesia teks sudah bukan hal yang asing. Teks sudah termasuk kedalam komponen penting dalam pembelajaran bahasa Indonesia. Banyak teks yang terdapat dalam pembelajaran bahasa Indonesia. Contohnya teks Cerpen, teks Prosedur, dan masih banyak lagi jenis teks ya g dapat dipelajari dalam bahasa Indonesia. Teks sudah menjadi bagian dari komponen pembelajaran di sekolah. Dalam pembelajaran berbahasa tentunya tidak terlepas dari teks (Agustina, 2017). Teks cerpen, teks prosedur dan teks lingkungan sangat memungkinkan untuk dijadikan materi dalam pembelajaran bahasa Indonesia disekolah. Hal tersebut dikerenakan teks tersebut tidak hanya memiliki aspek kohesi dan koherensi, tetapi teks tersebut dapat dijadikan media pembelajaran yang dapat mengembangkan pola pikir siswa. Karena teks tersebut memiliki banyak manfaat untuk mengasah kemampuan berfikir siswa. Oleh sebab itu, teks tersebut memiliki kemungkinan besar untuk digunakan dalam pembelajaran. Karena semakin banyak siswa menguasai teks, akan semakin banyak pula pengetahuan yang didapat siswa. 


\section{BAB IV \\ PENUTUP}

\section{A. Simpulan}

Wacana memiliki unsur pendukung yang sangat lengkap dan kompleks. Unsur tersebut terdiri atas unsur verbal (linguistik) dan unsur nonverbal (nonlinguistik). Wacana juga memiliki hubungan antarbagian wacana. Hubungan antar bagian wacana ada dua jenis, yaitu (1) hubungan bentuk yang disebut kohesi( cohesion) dan hubungan makna atau hubungan semantis yang disebut ( coherence). wacana

Pada teks cerepen "kembang api pembawa petaka" ditemukan data-data yang mengandung kohesi leksikal, yang ditunjukan dengan penggunaan kata, frasa, klausa dan kalimat yang mengandung piranti kohesi gramatikal berupa (1) pengulangan kata), (2) sisnonim (persamaan kata), (3) hiponim (Relasi kata), (4) meronim (Bagian kata) dan (5) antonym ( perlawanan kata) setra Pada koherensinya terdapat (1) hubungan sebab, (2) hubungan alasan dan (3) hubungan konsekuensi.

Pada teks prosedur terdapat kohesi penunjukan yaitu, kohesi anaforis dan kataforis, dan kohesi penggantian, kohesi perangkaian, kohesi pelepasan, dan pada koherensinya terdapat koheresi wacana eksposisi, koherensi wacana deskripsi, koherensi wacana narasi, koherensi wacana procedural, koherensi wacana dialog.

Pada teks lingkungan terdapat kohesi gramatikal penunjukan anaforis, kohesi penggantian dan koherensi kronologis serta koherensi kontras. Ketiga teks tersebut memungkinkan untuk dijadikan materi dalam pembelajaran bahasa Indonesia. Hal tersebut dikarenakan ketiga teks tersebut sudah memiliki aspek kohesi dan koherensi yang berbedabeda. Ketiga teks tersebut berperan penting dalam pembelajaran teks disekolah.

\section{B. Saran}

Menurut penulis makalah ini masih memiliki berbagai kekurangan dan masih jauh dari kata sempurna. Oleh karena itu kritik yang baik dan membangun sangat penulis harapkan. 


\section{KEPUSTAKAAN}

Agustina, E. (2017). Pembelajaran Bahasa Indonesia Berbasis Teks: Representasi Kurikulum 2013. Aksara, 18(1), 241049.

Andayani. (2015). Problematika dan Aksioma dalam Metodologi Pembelajaran Bahasa Indonesia. Yogyakarta: Deepublish.

Amelia, R., Sukma, E., dan Asma, N. (2015). Pembelajaran Menulis Laporan Percobaan dengan Pendekatan Saintifik di Sekolah Dasar. Prosiding Seminar Nasional Jurusan PGSD FIP UNP, 1(1), p 1-8.

Arviyana, M., Syahrul., dan Tressyalina. (2017). Pengaruh Model Discovery Learning Berbantuan Media Audiovisual terhadap Keterampilan Menulis Teks Prosedur Siswa Kelas VII SMP Negeri 12 Padang. Jurnal Pendidikan Bahasa dan Sastra Indonesia, Vol 6.(2), p 183-191.

Baryadi, Praptomo. 2002. Dasar-dasar Analisis Wacana dalam Ilmu Bahasa. Jogjakarta: Pustaka Gondho Suli.

Hanafiah, W. (2014). Analisis Kohesi dan Koherensi pada Wacana Buletin Jumat. Epigram, 11(2), p 135-152.

Insani, H, R \& Goziyah. 2018. "Kohesi dan Koherensi dalam Koran Bisnis Indonesia dengan Judul Kememperin Jamin Serap Garam Rakyat”. Jurnal Penelitian Pendidikan Bahasa Indonesia, Daerah, dan Asing. Volume 1. Nomor 1. Halaman 138-153. Diunduh 28 Mei 2020.

Isodarus, P. (2017). Pembelajaran Bahasa Indonesia Berbasis Teks. Jurnal Ilmiah Kebudayaan Sintesis, 11(1), 1-11.

Putri, I., Atmazaki, \& Syahrul R. (2013). Pelaksnaan Lesson Study Dalam Pembelajaran Bahasa Indonesia Siswa Kelas VII.5 MTs N Lubuk Buaya Padang. Jurnal Bahasa, Sastra Dan Pembelajaran, $\quad 1(1), \quad 108-117$. ejournal.unp.ac.id/index.php/bsp/article/download/5031/3983\%0A\%0A

Ramadhan, S., Sukma, E., \& Indriyani, V. (2019). Education and Digital Media Literacy: The Use of Digital Media by Teachers in Middle Schools. https://doi.org/10.4108/eai.19-72019.2289531

Ramadhan, S., Sukma, E., \& Indriyani, V. (2019). Environmental education and disaster mitigation through language learning. IOP Conference Series: Earth and Environmental Science, 314(1). https://doi.org/10.1088/1755-1315/314/1/012054 
Siregar, S. 2019. "Analisis Kohesi dan Koherensi Wacana Bahasa Inggris". Jurnal Dewantara. Volume 7. Halaman 39-55. Diunduh 29 Mei 2020.

Sukma, E., Indrawati, T., Suriani, A., Padang, U. N., \& Padang, K. (2019). Penggunaan Media Literasi Kelas Awal di Sekolah Dasar Use of Early Class Literacy Media in Primary Schools. 3, 103-111.

Sukma,E., Mahjuddin, R., Amelia, R. (2017). Literacy Media Development in Improving Reading and Writing Skill of Early Class Students in Elementary School Padang Utara Padang. Advances in Social Science, Education and Humanities Research, 118(9), p $145-150$

Sukma, E., Mahjuddin, R., \& Habibi, M. (2018). Literacy media models in improving reading skill of early class students in elementary school. Journal of Counseling and Educational Technology, 1(2), 33. https://doi.org/10.32698/041

Syofiani,. Zaim, M., Syahrul, R., dan Agustina. (2018). Peningkatan Keterampilan Berbahasa Siswa melalui Pemanfaatan Media Teka-Teki Silang: Menciptakan Kelas yang Menyenangkan. Jurnal Ta'dib, 21(2), p 87-97.

Widyaningrum, H, K. 2017. "Analisis Kohesi dan Koherensi Iklan dalam Surat Kabar Kompas". Jurnal Bahtera. Volume 4. Nomor 7. Halaman 1-11. Diunduh 19 Mei 2020.

Yantama, S. P., Syahrul, R., dan Afnita. (2013). Penerapan Pembelajaran Berbasis Masalah dalam Pembelajaran Teks Puis untuk Siswa Kelas VIII SMP Negeri 4 Sungai Penuh. Jurnal Pendidikan Bahasa dan Sastra Indonesia, 1(3), p 104-114. 